\title{
The Employability of Non-Native-Speaker Teachers of EFL: A UK Survey ${ }^{1}$
}

\begin{abstract}
The native speaker still has a privileged position in English language teaching, representing both the model speaker and the ideal teacher. Non-native speaker teachers of English are often perceived as having a lower status than their native-speaking counterparts, and have been shown to face discriminatory attitudes when applying for teaching jobs. To date, research into the employment of non-native speaker teachers has been carried out only in the United States; this study extends that research by providing data on the United Kingdom. Questionnaires were distributed to those responsible for recruitment at English language teaching institutions in the UK in order to investigate the extent to which employers regard being a native English speaker as an important criterion when making hiring decisions. $72.3 \%$ of the 90 respondents judged the 'native English speaker criterion' to be either moderately or very important. The conclusion that employers regard this criterion as important was shown to apply to the whole sample as well as to the separate groups of private language schools only and universities only. As a pre-interview criterion, the 'native English speaker criterion' thus excludes competent English language teachers from consideration in the recruitment process.
\end{abstract}

\section{Introduction}

In October 1991, the TESOL organisation in the United States issued a statement condemning as discriminatory the employment of English language teachers on the sole basis of their being or not being native speakers of English (TESOL, 1991, cited in Braine, 1999b:xxi). Fifteen years later, as a result of globalisation and the expansion of the EU, probably more non-native speaking teachers of English are seeking work in nativespeaking countries like Great Britain and the USA than ever before, making the issue of employment discrimination even more pertinent.

\footnotetext{
${ }^{1}$ We would like to thank three anonymous reviewers for their helpful comments on an earlier draft of this paper.
} 
Yet these teachers are still marginalised in their profession, as numerous researchers and a number of volumes of collected articles (e.g. Braine, 1999b; Kamhi-Stein, 2004; Llurda, 2005) have shown. One study (Mahboob, Uhrig, Newman, \& Hartford, 2004), on which the present study is based, looked specifically at employers' attitudes towards the 'native speaker criterion' in English Language Teaching (ELT) recruitment in the American tertiary sector, concluding that employers consider this criterion to be important when making recruitment decisions. Mahboob et al also found that there is a negative correlation between the importance placed on this criterion and the number of non-native English-speaking (NNES) teachers employed at a particular institution, that is, the higher the importance of this criterion, the fewer NNES teachers were employed there.

Mahboob et al (2004) was the first study to investigate this issue in an English-speaking country. This paper describes a study which investigated to what degree the same is true for ELT employers in the United Kingdom, where little research into this field has been carried out. With adaptations to the questionnaire for the British context, ELT employers were surveyed about their criteria for employing English language teachers. In this way, our findings have allowed an analysis of the relative importance to employers of a teacher's 'nativeness', thus building on the work of Mahboob et al (2004).

\section{Native speakers, non-native speakers, and language teaching}

\subsection{Defining NES and NNES}


The concepts of 'native English speaker' (NES) and 'non-native English speaker' (NNES) are not easily definable, partly because the language itself has so many varieties. Although the full extent of NES variation may not be entirely relevant to ELT - as Medgyes (1992:343) points out, NNES teachers should be compared with NES teachers, not 'Scottish shepherds or twelve-year-old Australian schoolchildren' - the lack of equivalence between standard English and native English problematises the construct of native English speaker in particular. English has official status or is widely used in over 75 territories in the world (Crystal, 2003a: 109) and it is a matter of debate which of the world's Englishes are native varieties. Singaporean English, for example, is both a home language and a second language (Foley, 2006), and thus Singaporeans could be seen by some as NESs and by others as NNESs. Even in traditionally monolingual, 'inner circle' (Kachru, 1985) countries, such as England, there are growing numbers of bi- or multilingual people thanks to immigration. Existing ethnic and linguistic categories may not adequately describe the complexity of an individual or a community's language use, as a person's so-called native language is not necessarily their strongest or the one they identify most closely with (Leung, Harris, \& Rampton, 1997).

In response to this debate, some scholars have argued that 'native speaker' and 'nonnative speaker' are simplistic or even misleading labels that should be replaced by more precise definitions. Rampton (1990), for instance, proposes 'expert speaker' instead of 'native speaker', to reflect 'language expertise', which is contrasted with 'language inheritance' and 'language affiliation'. Other suggestions include 'more' or 'less accomplished', and 'proficient users of English' (Edge, 1988; Paikeday, 1985, both cited in 
Reves \& Medgyes, 1994). However, others, for example Medgyes (1992), argue that suggested replacements do not stand up any better to close examination than the original terms. Most ELT practitioners continue to use the term 'native', although it is often qualified these days with the add-on 'or near-native'. Thus the emphasis on language competence does not seem to have removed the use of the NS/NNS labels. (This issue, however, does have implications for any study of this topic; we discuss this in Section 3.1, Questionnaire Design, below.)

\subsection{The NS in ELT: Model Speaker and Ideal Teacher}

It is this elusive concept of 'native speaker' that is provided as a model for language learners and against which they are measured. For example, although some textbooks now feature learners of English in dialogues intended for listening practice, most teaching materials still focus on NESs interacting with one another. In cases where learners are featured, they may in fact be played by NES actors. Students aspire to an NES norm, even those who anticipate mainly using English with other NNESs (Timmis, 2002). What follows from this assumption that the native speaker is the model for language learners, is the view that the native speaker should be the one teaching them, too. This idea was reinforced theoretically by the Chomskyan conceptualisation of the (idealised) NS as the source of knowledge about language (Braine, 1999b:xv; Canagarajah, 1999). In practice, it might seem reasonable to say that students would benefit from a native-speaking teacher with 'perfect' knowledge of the language and pronunciation. 
There are two lines of objection to this position. The first is that students are in fact most likely to use English with other NNESs, as NNESs now far outnumber NESs: Crystal (2003b: 67-9) puts the number of English speakers in the world at 1,500 million, of whom only 400 million are L1 speakers. And, as Cook (1999) points out, the language competence of a monolingual (which is the standard conceptualisation of the native speaker) is very different to an L2 speaker's 'multicompetence'. Therefore, even for very advanced speakers, the native speaker yardstick is an unsuitable measurement (Piller, 2002). A similar claim is made by the supporters of the view that English as a Lingua Franca (ELF) is emerging as a variety in its own right, and that NESs have lost the ownership over the language (if indeed such ownership can ever be claimed) (see, for example, Jenkins, 2000; Seidlhofer, 2001; Widdowson, 1994).

The second line of objection, where teachers are concerned, is that language competence is only one of the skills needed to teach a language successfully. Reves and Medgyes (1994), who surveyed 216 English teachers in 10 countries, found that their respondents claimed that there are differences between NES and NNES teachers in their teaching styles, which result mainly from differences in language proficiency. But their respondents did not agree that just because NES teachers are more fluent speakers, they are automatically better teachers. They believed that NNES teachers are often better prepared, more empathetic and more knowledgeable about English than NES teachers. Indeed, the NES teachers interviewed by Árva and Medgyes (2000) commented on their own inability to empathise with the learners' difficulties, compared with NNES teachers. 


\subsection{NNESs in ELT}

This is not to argue that NNES teachers are automatically more capable than NESs.

Indeed, Braine (1999a: 23) points out that students' resistance to NNES teachers in ESL settings may be a result of their 'frustration with incompetent, barely proficient English teachers in their own countries'. Yet this only supports the argument that English teaching is a professional skill, to be acquired through training and experience, and not the preserve of any particular group.

Having said that, there are several areas where NNES teachers have an advantage over NES teachers, including the increased empathy for learners, as Medgyes (1994) points out. Nemtchinova (2005), in her study of how NNES trainee teachers in the US were viewed by host teachers during their teaching practice, also comments on this empathy and suggests that it was 'a distinctive attribute that the NNES brought to their classrooms'. Indeed, she found that the trainees were positively regarded in various areas, including their ability to act as a model of 'successful language learning', because they were non-native speakers.

This empathy, or the ability to view the learning of English from the students' perspectives, may be particularly valuable in the teachers' home countries where they share the students' linguistic and cultural backgrounds. A crucial advantage for NNESs in these countries is their ability to use and understand their students' first language in the classroom, which can be a source of teacher confidence (Seidlhofer, 1999). However, despite evidence to show that there are cognitive (Canagarajah, 1999) and pedagogical (Cook, 2001) benefits to L1 use in second language learning, the prevailing ideology is that 
'English only' is the best way (Cook, 2001). The EFL industry, which is dominated by NES-produced materials and methodologies arising from the multilingual classrooms of English-speaking countries, is seen to support this ethos (Cook, 2001). It benefits monolingual NESs as it upholds their privileged status and means that they do not have to learn their students' first languages, despite the fact that very few British or American teachers would have experienced learning other languages without the use of English (Phillipson, 1992:188). Many schools in EFL settings that advertise for NES teachers stress that they do not need to be able to speak the local language. For practising conversation, some students may even prefer the teacher not to know their language, as there is more motivation to use the L2 with a teacher who does not speak the L1 (Árva \& Medgyes, 2000).

Moreover, in countries where English is spoken as a native language, even this factor, knowledge of the students' L1, ceases to be an advantage, and indeed ceases to be any factor for consideration. There, students come from all over the world, and the language of instruction is necessarily English, meaning that NNES teachers do not have the potential advantage of being able to act as 'double agents' or experts mediating between two languages and cultures (Seidlhofer, 1999). Instead, NNES teachers face entrenched linguistic discrimination, in both their daily and professional lives. Lippi-Green (1997) reveals how NNESs in the US are discriminated against because of their accents (although her work is not specifically about teachers). She reports on evidence suggesting that speakers of the dominant variety may refuse to take an equal share of the responsibility 
for successful communication when talking to 'a person with an accent' (1997:70). In the

UK, research into communication in multiethnic workplaces concludes that,

The greatest hurdle for ethnic minorities with regard to language is the failure of white-Anglo gatekeepers to make sound judgements about ethnic minority groups' knowledge of English and the tendency of such gatekeepers to draw incorrect conclusions from the way non-Anglos use English (Roberts, Davies, \& Jupp, 1992:368).

In ELT, where issues of language are obviously more salient than in most professions, employers' and students' preference for NES teachers means that NNES teachers can be turned down for jobs as a matter of course. Braine (1999b:xvi) observes that 'in the case of non-native teachers operating in ESL contexts, no issue is more troubling than that of discrimination in employment'. He describes how he 'was turned down almost instantly' when he applied for a teaching position at the university where he was doing his Master's degree, while 'some NS classmates who had no teaching experience were employed' (1999a: 22). He argues that many NESs in ELT, although they may oppose discrimination in principle, do discriminate against NNESs when recruiting English language teachers (1999b: xvi).

The 'excuse' given by employers for favouring NESs over NNESs (Braine, 1999b: xvii) is that students apparently prefer to be taught by NESs. However, these preferences may only be a reflection of the pro-NES attitudes of ELT materials, schools and teachers, as Thomas (1999) points out: 'we usually learn to value what we see valued and to undermine what we see undermined'. One UK-based study (Pacek, 2005) indicates that 
students' expectations (based on what they thought were desirable qualities in a language teacher) were in fact broadly met by an NNES teacher at their university and that students were less critical of or negative about the teacher than had been expected. However, this was a small-scale study which only considered attitudes to one teacher, who many of the students were unaware was an NNES. Students' preferences can also affect NNES teachers' self-confidence (Thomas, 1999), which is 'a necessary ingredient of successful teaching' (Reves \& Medgyes, 1994). In this way, the anti-NNES bias becomes a vicious circle, contributing negatively both to students' attitudes and thus to teachers' self-belief as professionals.

The issue of the recruitment of NNES teachers in ESL is the focus of Mahboob et al (2004), which is the basis for the present study. Mahboob et al discuss the importance placed by recruiters of ESL teachers on various criteria, including the NES-NNES status of prospective employees, in the US. Programme administrators from 122 university-level intensive English programmes rated 10 criteria for teacher recruitment on a six-point scale. The results show that administrators were split on the native English speaker criterion, with most respondents choosing either the high end or the low end of the scale. The importance attributed to the NES criterion was then shown to correlate negatively with the number of NNESs employed as English instructors in particular programmes, while the criteria of educational experience, teaching experience and recommendation did not correlate, suggesting that the NES criterion is more significant in recruitment decisions. The study implies overall that if NNESs apply for employment as English language instructors, they may be judged negatively on the basis of their NNES status. 
No such data exists for the UK, except for an informal survey of 'a group of highly sophisticated ELT specialists' in London by Medgyes (1992:343). He received around 60 responses to questions relating to what participants' hiring preferences would be in terms of NESs and NNESs if they were the head of a private language school in Britain. He found that no one chose the first option, to hire only NESs, but concludes that this was a reflection of the sample: the kind of people who would discriminate against NNESs 'are not welcome at distinguished professional gatherings' (p. 344).

Apart from Medgyes (1992) and the case study by Pacek (2005), no research in this field has been conducted in the UK. This is despite the fact that ELT is potentially a major employer in the UK of non-Britons - for two reasons. Firstly, it can be supposed that the numbers of NNES teachers looking for work in the UK may rise with the recent expansion of the EU and corresponding increase in the number of EU citizens with the right to live and work in Britain. (We should, however, note at this stage that data in this area is hard to come by. There are no central statistics on teachers in ELT in the UK, and despite queries to a number of organisations about this, we have not been able to come up with any satisfactory data). Secondly, English can still be viewed as a boom industry - indeed, according Gordon Brown, Chancellor of the Exchequer, quoted in EL Gazette, (2005), English is tipped to be 'the UK's biggest foreign currency earner'. For these reasons, discrimination in employment in ELT, that is, against NNES teachers, could have political and economic consequences, as well as raising questions about the academic integrity of its institutions. 


\subsection{Research Questions}

The present study investigated to what extent the conclusions of Mahboob et al (2004) are applicable to the UK ELT sector. Specifically, the study aimed to answer the following research questions:

1. What criteria do employers in the UK ELT sector consider when recruiting English language teachers?

2. Relative to other criteria, what importance do employers in the UK ELT sector place on a teacher's being a native English speaker (the 'NES criterion')?

3. What is the relationship between the importance placed on the NES criterion and the employment of NNES teachers by the UK ELT sector?

\section{Methodology}

\subsection{Questionnaire Design}

The data was gathered from ELT institutions through an emailed questionnaire (see Appendix I). The questionnaire was based on that of Mahboob et al (2004), but was modified in two significant ways.

Firstly, to reflect the strongly seasonal nature of student and teacher recruitment in Britain, we asked respondents to give the number of students and teachers in their institutions in the summertime and in the rest of the year (Questions 5 and 7). However, in order to limit the number of NNES-related questions, respondents were not asked to divide NES and NNES teacher numbers into the two seasons (Question 8). 
Secondly, we made several changes to the section in which respondents rate criteria for employing teachers (Question 11). The original Likert scale was problematic as the descriptor used - ' 0 being the least important and 5 being the most important' - implied that respondents had to rank, not rate, the criteria. An additional change was to provide descriptors for each point of the scale (rather than only the end points) in order to lower the subjectivity of participant interpretation of each rank. Next, we changed the scale from six points to five and included a 'not applicable' category. We also adapted the criteria list to the UK context to remove potential overlap ('citizenship' and 'nationality'; 'accent' and 'dialect') and to include possibly important considerations (such as 'performance in interview', 'teaching qualifications', and 'visa status') that were missing. Lastly, we added a section for respondents to add their own criteria (Question 12), as recommended by Mahboob et al.

A possible limitation of the research design is that no definition of 'Native Speaker' was provided for the respondents. However, providing a definition or an example would likely create other problems. Mahboob et al say that 'the term native here includes American, Australian, and British English, and so on' (2004). It is not clear whether this definition was provided in the questionnaire itself, but it is easy to see that it does not define native, but rather defines a geographical spread where this 'nativeness' might be found. In our study, we assume that by the term Native Speakers the respondents understood, roughly, a person born in a country where English was the dominant language, and raised and educated in English from birth or from a young age. Providing a 
complex definition might well have raised other issues and questions (just as the simple definition here raises a host of issues). It could have excessively influenced the responses and would also have drawn too much attention to the native speaker issue on an ostensibly general questionnaire.

\subsection{Selection of Participants}

Another difference is that Mahboob et al targeted university employers exclusively, while we sent questionnaires to three different institution types, as the UK university sector is relatively small. The three types of institutions were:

(1) private language schools (British Council accredited); this category included a number of independent schools which ran summer EFL classes.

(2) universities and other HE institutions, and

(3) FE (Further Education) institutions.

Most respondents belonged to the British Council-run English in Britain Accreditation Scheme (EiBAS) (British Council, 2005), now also known as Accreditation UK, which sets standards for teacher qualifications. Non-accredited private language schools were excluded from the sample, as they do not follow such standards (Sherr, Cheung, \& Harding, 2004) and thus potentially vary widely in their recruitment criteria.

As most EiBAS members are private language schools, we also contacted some nonmember universities in order to increase representation from the tertiary state sector. Finally, we asked members of IATEFL internet discussion lists (see IATEFL, 2005) to volunteer to fill out the questionnaire if they were responsible for recruitment of English 
language teachers in the UK. After eliminating institutions that were not contactable by email, a total of 325 institutions were identified (see Table 1 for a breakdown by institution type).

\subsection{Questionnaire Distribution and Response}

Following a small pilot study in which no technical or other difficulties were identified, the questionnaire was emailed to those responsible for teacher recruitment at the 325 institutions. When personal email addresses were not provided on the institutions' websites, we used the general email address and marked the message for the attention of the Director of Studies or Human Resources Manager. The questionnaire was then returned as an email attachment or printed and returned by post. As Mahboob et al recommend, the first email was followed by a reminder email after 1-2 weeks.

Table 1 shows the response rate overall and by institution type for the 325 institutions we contacted. The overall response rate is similar to that of Mahboob et al (2004), which was $25.5 \%$

INSERT TABLE 1 HERE

\section{Results}

\subsection{All Recruitment Criteria}


Table 2 provides an overview of the results, through a calculation of mean, mode and standard deviation. This reveals that 'teaching qualifications', 'performance in interview', 'teaching experience', 'educational background', 'recommendation', 'visa status' and 'native English speaker' have a mean of 4 or above and a mode of 5, suggesting that these are the most important criteria for recruiters. Mahboob et al found a mean of 4 or above and a mode of 5 only for 'teaching experience' and 'educational experience'. However, the order of the criteria in terms of mean ratings generally corresponds to their findings.

(Note also that Mahboob et al were using a 6-point scale, from 0-5, whereas we were using a 5-point scale, from 1-5. This does not affect comparisons where the mode is concerned, as the highest point on both scales is a 5, but it does affect comparisons of the means, and a mean of 4 in our study represents a higher overall trend than in Mahboob et al.)

\section{INSERT TABLE 2 HERE}

Table 3 provides a more detailed analysis of the results according to the number of responses for each criterion, and what percentage of the total those responses were. This makes it possible to take into account the 'Not applicable' option, plus 'no answer'. If the ratings of 4 (moderately important) and 5 (very important) are collapsed for the seven criteria with mean ratings of 4 or above, 'teaching qualifications' (87/90 respondents chose 4 or 5 , which is $96.7 \%$ of the total), 'performance in interview' and 'teaching experience' (both $86 / 90$ or $95.6 \%$ ) receive the highest scores. No respondents chose 1 (not important at all) or 2 (relatively unimportant) for 'teaching qualifications' or 'performance in interview'. 'Educational background' follows with $80 / 90$ or $88.9 \%$, and then 
'recommendation' with 73/90 or 81.1\%. 'Native English speaker' is next with 65/90 or $72.3 \%$, while 'visa status' only received $44 / 90$ or $48.8 \%$ with 28 'Not applicable' responses.

As for the lowest ratings, more respondents chose 1 (not important at all) and 2 (relatively unimportant) for 'ethnicity' (58/90 or $64.5 \%)$ than any other criterion. No respondents rated it as 4 or 5 , and $27.8 \%$ chose 'Not applicable' or gave no response. Next lowest was 'British nationality', with $47 / 90$ or $52.3 \%$ of respondents choosing 1 or 2 , and $17.8 \%$ responding N/A or giving no response. The highest rate of N/A or no response was for 'teaching demonstration' (32.2\%).

The N/A category is an interesting category which seems to have been open to interpretation. Some respondents may choose it because a category does not apply (e.g. they do not use a teaching demonstration) while others may use it because they consider a category to be so unimportant as to be not applicable. The difference may be demonstrated by the high numbers of N/A answers for 'EU nationality' and 'ethnicity'. For the former, it may be the case that respondents marked it as N/A because many applicants outside the UK would not be considered because of legal reasons (i.e. visa status, which is another criterion which many participants marked as not applicable).

Where 'ethnicity' is concerned, on the other hand, respondents may truly consider it a non-applicable criterion in and of itself (with this category possibly overlapping with the 'Not important at all' category). The term 'ethnicity' could also have had various interpretations, including skin colour, race, nationality, or religious, linguistic or cultural 
group. In view of the contrast between responses for the NES criterion and those for ethnicity, it may be suggested that respondents did not interpret it as closely linked with nationality or 'nativeness'. However, without specified definitions for these two categories, no clearer conclusions can be drawn. (See also Block [2007:28-29] for a discussion of the problems inherent in defining ethnicity and the lack of definition of this construct in the research literature).

\section{INSERT TABLE 3 HERE}

\subsection{The Native English Speaker Criterion}

\subsubsection{All Respondents}

A large majority of respondents (72.3\%) consider their employees' being NESs either moderately or very important (see Figure 1). The curve in Figure 1 illustrates a preference among respondents for the upper end of the scale, in contrast to the ' $U$-curve' (respondents preferred either the lower or upper end of the scale) in Mahboob et al. The trend applies to the whole sample and to the different institution types considered separately (private language schools, universities and HE institutions, and FE colleges).

\section{INSERT FIGURE 1 HERE}




\subsubsection{Private Language Schools}

Figure 2 indicates the percentages for each response for the NES criterion for private language schools $(\mathrm{N}=50)$. The importance placed on this criterion by private language schools is slightly greater than for the sample as a whole. Thirty-nine of 50 respondents from private language schools, or $78 \%$, answered 4 or 5 to this question (compared with $72.3 \%$ for the whole sample).

\section{INSERT FIGURE 2 HERE}

\subsubsection{Universities}

The respondents from universities (all 27 were universities, rather than other types of HE institution) placed less importance on the NES criterion than those from private language schools, as Figure 3 shows. 66\% (18 cases) of respondents chose 4 or 5, compared with $72.3 \%$ for the whole sample. Yet the relative weighting of each response is the same for both groups, and the whole sample: 5 received the most responses, followed by 4, and so on. It should also be noted that the 27 responses represent $23.1 \%$ of all 117 university institutions in the UK (Universities UK, 2004).

\section{INSERT FIGURE 3 HERE}

\subsubsection{FE Colleges}


This is the smallest group of the three $(\mathrm{N}=13)$ and as such the following results (shown in Figure 4) should not be used as a basis for drawing any conclusions. They are presented here for information only, and to highlight the fact that in all three groups, the highest numbers of responses were in the 4 (moderately important) and 5 (very important) categories. There is some indication that the NES criterion is less important here than in the two other sectors, since the percentage of responses in the 2 (relatively unimportant) and 1 (not important at all) categories was higher in this sector than in the two other groups. However, because of the small numbers this can only be a very tentative suggestion.

\section{INSERT FIGURE 4 HERE}

\subsection{Employment of NNES Teachers and NES criterion}

Calculating the ratio of NES to NNES teachers, as Mahboob et al (2004) did, ultimately proved to be problematic because of the difficulty of obtaining a clear picture of the number of teachers represented in the study. It was not made apparent to respondents whether they should give the summertime figures or those for the rest of the year when filling in the number of NES and NNES teachers they employed. Besides, fluctuating staff levels in the summertime (which is when the questionnaires were distributed) meant that many respondents chose to give a range (such as '15-20') or a percentage (such as $80 \%$ female, $20 \%$ male) instead of one figure. 
However, it is possible to examine the relationship between the importance accorded to the NES criterion in institutions that employ NNESs and those that do not. At the time of response, 62 institutions of a total of 90 (68.9\%) did not employ any NNES teachers, while $26(28.9 \%)$ did (two did not provide any information about the teachers that they employ). Table 4 presents a cross-tabulation between the NES criterion and employing NNESs (five institutions were excluded from this table because of a 'not applicable' response or no response to one of the two questions.) Firstly, note that the 'yes' respondents ( $N=24)$ number less than half of the 'no' respondents $(\mathrm{N}=61$ ). Secondly, note that only $50 \%$ of the 'yes' respondents chose 4 or 5 for the NES criterion, compared with $85 \%$ of the 'no' respondents. Only $8 \%$ of institutions that do not employ NNES (five institutions) marked this criterion as not important at all or relatively unimportant. The corresponding percentage among the institutions that employ NNES is $25 \%$ (six institutions). This suggests that employers who believe that being an NES is important are less likely to hire NNESs as teachers. This of course assumes that NNESs are applying for vacant positions in the first place. It could well be the case that in many of the institutions, no applications have been received from NNESs, and from this perspective conclusions from the results of the cross-tabulation can only be tentatively drawn.

\section{INSERT TABLE 4 HERE}

\subsection{Teachers' Countries (Table 5)}

Thirty respondents (33.3\%) indicate employing non-British NESs and 26 (28.8\%) employ NNES teachers (nine institutions are in both groups). Of the 16 countries listed for NNES 
teachers, 11 are EU member states (Turkey, Argentina, Russia, Switzerland and Taiwan are not). In contrast, most non-British NESs come from outside of the EU (although, of course, the Republic of Ireland is the only native English-speaking EU country other than the UK).

\section{INSERT TABLE 5 HERE}

\subsection{Other Recruitment Criteria}

45 of the 90 respondents (50\%) listed additional criteria that they use in the recruitment of English language instructors. We categorised these additional criteria into eight themes (see Appendix II for a full list of responses):

- personality/attitude

- other personal characteristics

- specialised experience

- knowledge or qualifications

- language-related

- legal status

- probation

- institution-specific issues

- other.

Personality/attitude, such as 'lively/enthusiastic', 'friendly' and 'flexibility'/'adaptability', was the most frequently mentioned (listed by 23 respondents). The second most 
commonly mentioned criterion (21 respondents) was specific qualifications or experience, such as 'overseas teaching experience', or experience in /knowledge of EAP (English for Academic Purposes). Interestingly, more than half of the responses in this category came from the University sector, with more than a third of respondents in this category choosing to add a comment.

Perhaps most relevant to the NNES teacher question is a 'legal' group of criteria, which includes being 'able to supply CRB [Criminal Records Bureau] check' or being legally able to work in the UK. Respondents sometimes used this to clarify a response to the 'visa status' or 'EU nationality' criteria, as the following comment shows:

'For EU nationality \& for Visa Status I have ticked the relatively unimportant box, but I'd like to qualify that by saying that this is true as long as the employment of the individual is legal and in line with UK law.'

Of course, this type of legal issue can apply to any teacher, NES or NNES, and none of the six respondents who commented on this specified either group.

\section{Discussion}

In response to the question posed in this research - Is being a native speaker important for employers of English language teachers in the UK? - we can confidently say that it is. Almost three quarters (72.3\%) of respondents consider a job applicant's being an NES either moderately or very important. This finding is consistent for the whole sample, private language schools only (78\%), and universities only (66\%), with some indication 
that this is less so for the FE sector. The results of this study are therefore in line with Mahboob et al's (2004) conclusions that in the US the NES criterion is an important factor in hiring. In fact, the proportion of respondents answering 1 or 2 for the NES criterion was lower for these UK results than for Mahboob et al's US respondents.

Not only do employers think being an NES is important, but they also make hiring decisions based on it. According to the cross-tabulation, NNESs are less likely to be employed by those recruiters in this sample who believe that being an NES is important. (We are aware that the person answering the questionnaire may not have been the same person who hired the staff in the first place, but this is nevertheless an indicator of an institution's stand on this matter.) Although 26 of the 90 respondents reported that their institutions employ NNESs, a greater number (30) employ non-British NESs. Moreover, most of the NNES teachers are from EU countries, while the non-British NES teachers are not. This implies that institutions are more willing to employ non-EU teachers - and possibly find a way around the ensuing legal issues - if they are NESs. Conversely, employers seem to be more willing to employ NNESs if they are EU citizens. However, more information about the visa status of the non-British teachers would be needed before this could be confirmed.

Certainly, the NES criterion was not the only one judged to be important by the respondents. Six other criteria (without taking into account non-responses) received a higher mean rating. More respondents chose 4 or 5 for 'teaching qualifications', 'performance in interview', 'teaching experience' and 'educational background' than for 
'NES'. Additional criteria listed by respondents show that 'personality', or as one respondent put it, 'gut reaction', can be fundamental. Indeed, NNESs may be judged favourably on some of the additional criteria listed, such as 'empathy with other cultures' or 'overseas experience'. However, even if other criteria are considered, if an employer thinks 'NES' is 'very important', it may very well be the case that a candidate will be ruled out from consideration no matter how strong her or his teaching qualifications or educational background. This is compounded by the fact that 'NES' is most probably a pre-interview criterion; even where an application form might not ask for this information, it may be apparent from details such as place of birth, nationality, and educational history. This means that if a recruiter judges that a person is an NNES, and if the recruiter considers that criterion to be important, then the applicant will not be invited for interview. (See also Medgyes [1994:9], where he recounts the story of a teacher who ‘had not even been granted the opportunity for a job interview to prove her native-like proficiency'.)

The data in Figures 1-3, however, serves as some indication that the FE sector may be different from the Private and the University sectors. Additional support for that comes from anecdotal evidence and our personal acquaintance with NNES teachers in the FE sector (some of whom also teach minority languages, such as Turkish, which may have played a role in their appointment). In addition, support comes from examining the ratio of NES to NNES on the PGCE Adult Literacy and ESOL run at the Institute of Education, University of London (the workplace of the second author). Over the four years that the course has run, 19 of 71 students on the ESOL pathway have been NNES (Irene Schwab, 
personal communication, 17 March 2007). Since this is a course for serving teachers in the FE sector in the UK, this may be an indication that, within this sector, at least, there is a relatively high proportion of NNESs.

For a fuller picture, more information is needed about recruitment procedures and the thinking behind the responses. For example, we do not know how many NNESs and NESs apply for each vacant position or how employers decide if an applicant, or indeed a member of staff, is an NES or an NNES. This type of data is difficult to get and is not publicly available (Tony Millns, personal communication, 15 February 2007). In addition, what the respondents state their criteria to be may not correspond with what they actually do during the hiring process. A person who does not consider the NES criterion to be important may nevertheless only recruit NESs, if there are a large number of applications, taking what they consider to be a pragmatic approach in light of apparent student preference for NESs. These and other relevant issues could be revealed with interviews with employers.

Another limitation of this research is the relatively small size of the sample. Nonaccredited institutions and those without functioning websites or email addresses were not contacted. Of the 325 institutions that were contacted, only 90 responses were collected. However, even if all of the non-respondents had rated the NES criterion as 1, 2 or 3 , which is rather unlikely, that would still leave $20 \%$ (65 respondents out of a total of 325) who chose 4 or 5 . This is, at the very least, a large minority. Moreover, the 90 responses came from a variety of institutions from all over the UK, rather than just the HE 
sector, as was the case in Mahboob et al's (2004) study. Indeed, it may be suggested that the apparent greater preference for NESs at private language schools compared with FE colleges and universities may reflect the fact that the latter, as publicly-funded institutions, have a greater responsibility and accountability in terms of transparent, nondiscriminatory employment practices.

Although the study was not a complete replication of Mahboob et al's (2004) research, it did reproduce its main focus: the quantitative measurement of employers' attitudes to the NES criterion. The results therefore strongly support Mahboob et al's conclusions that NNES teachers are, in effect, "children of a lesser English". While other criteria are important too, and the legal status of a candidate is a consideration, NNES teachers applying for work in the UK will still encounter negative responses to their NNS status.

\section{Conclusion}

The criteria used by ELT employers to assess applications from NNES teachers matter because they affect teachers' employment prospects. If employers take a negative view of a teacher's non-native status, English teachers who are fluent, well qualified and experienced, and who have the legal right to work in Britain, may struggle to find employment because of their NNES status. They are unlikely even to be invited for interview.

The results of this study confirm that this is a fair description of the challenge faced by an NNES teacher in the UK. If s/he applies for a teaching job, their lack of native speaker 
status will be viewed as an important consideration at over $70 \%$ of the institutions in this survey. It is also the case that trainers on short certificate courses tell their NNES trainees that they will have problems finding work in the UK (Book, 2007). This is against a background of fierce competition for jobs, especially full-time or permanent positions, in

\section{UK ELT.}

More research is needed to uncover the beliefs motivating employers' attitudes and the actual experiences of NNES teachers in Britain. Although this research demonstrates that the NES criterion is considered important, it does not explain why this is the case, nor does it generate specific recommendations to counter negative attitudes towards NNESs. It has been suggested that teacher education programmes can address the NNES teacher issue to increase NNES teachers' self-confidence and NES teachers' awareness (e.g. Kamhi-Stein, 1999; Samimy \& Brutt-Griffler, 1999). However, in Britain, the bulk of English language teacher training happens on short certificate courses, leaving little time for anything more than the bare essentials. Moreover, there is nothing to suggest that the teacher trainers on these courses will have different attitudes to the employers represented in this research, although there is research suggesting that once teacher trainers work with NNESs, they may well form positive impressions of them (Nemtchinova, 2005). Attitudes may only change as a result of the successes of the few NNES teachers who are employed in schools in the UK. In this way, the realisation that NNES teachers have much to offer to an international student body may gain ground, and criteria relating to teaching skills, such as qualifications and experience, may come to be 
valued far more by employers. At that point, we hope that the NES criterion will be considered irrelevant. 


\section{Bibliography}

Árva, V., \& Medgyes, P. (2000). Native and non-native teachers in the classroom. System, $28,355-372$.

Block, D. (2007). Second Language Identities. London: Continuum.

Book, J. (2007, 22 April). Non-native CERT trainees - dealing with language and cultural issues. Paper presented at the $41^{\text {st }}$ International Annual IATEFL Conference, Aberdeen Exhibition and Conference Centre, Aberdeen, UK.

Braine, G. (1999a). From the Periphery to the Center: One Teacher's Journey. In G. Braine (Ed.), Non-Native Educators in English Language Teaching (pp. 15-27). Mahwah, New Jersey: Lawrence Erlbaum Associates.

Braine, G. (Ed.). (1999b). Non-Native Educators in English Language Teaching. Mahwah, New Jersey: Lawrence Erlbaum Associates.

British Council. (2005). A-Z list of accredited centres. Retrieved 7 July, 2005, from http://www.britishcouncil.org/accreditation-search-az.htm

Canagarajah, A. S. (1999). Interrogating the "Native-Speaker Fallacy": Non-Linguistic Roots, Non-Pedagogical Results. In G. Braine (Ed.), Non-Native Educators in English Language Teaching (pp. 77-92). Mahwah, New Jersey: Lawrence Erlbaum Associates.

Cook, V. (1999). Going Beyond the Native Speaker in Language Teaching. TESOL Quarterly, 33(2), 185-209.

Cook, V. (2001). Using the First Language in the Classroom. Canadian Modern Language Review, 57(3).

Crystal, D. (2003a). The Cambridge Encyclopedia of the English Language (2nd ed.). Cambridge: Cambridge University Press.

Crystal, D. (2003b). English as a Global Language (2nd ed.). Cambridge: Cambridge University Press.

Edge, J. (1988). Natives, speakers and models. JALT Journal, 9.

EL Gazette. (2005, May). Brown backs English boom. EL Gazette, 1.

Foley, J. A. (2006). English as a lingua franca: Singapore. International Journal of the Sociology of Language, 177, 51-65.

IATEFL. (2005). International Association of Teachers of English as a Foreign Language Website. Retrieved 21 July, 2005, from http://www.iatefl.org/default.asp 
Jenkins, J. (2000). The Phonology of English as an International Language. Oxford: Oxford University Press.

Kachru, B. B. (1985). Standards, codification and sociolinguistic realism: the English language in the outer circle. In R. Quirk \& H. G. Widdowson (Eds.), English in the World: Teaching and learning the language and literatures (pp. 11-30). Cambridge: Cambridge University Press in association with the British Council.

Kamhi-Stein, L. D. (1999). Preparing Non-Native Professionals in TESOL: Implications for Teacher Education Programs. In G. Braine (Ed.), Non-Native Educators in English Language Teaching (pp. 145-158). Mahwah, New Jersey: Lawrence Erlbaum Associates.

Kamhi-Stein, L. D. (Ed.). (2004). Learning and Teaching from Experience: Perspectives on Nonnative English-Speaking Professionals. Ann Arbor: The University of Michigan Press.

Leung, C., Harris, R., \& Rampton, B. (1997). The Idealised Native-Speaker, Reified Ethnicities and Classroom Realities: Contemporary Issues in TESOL, CALR Occasional Papers in Language and Urban Culture. London: Thames Valley University.

Lippi-Green, R. (1997). English with an Accent: Language, ideology, and discrimination in the United States. London: Routledge.

Llurda, E. (Ed.). (2005). Non-Native Language Teachers: Perceptions, Challenges and Contributions to the Profession. New York: Springer.

Mahboob, A., Uhrig, K., Newman, K. L., \& Hartford, B. S. (2004). Children of a Lesser English: Status of Nonnative English Speakers as College-Level English as a Second Language Teachers in the United States. In L. D. Kamhi-Stein (Ed.), Learning and Teaching from Experience: Perspectives on Nonnative English-Speaking Professionals (pp. 100-120). Ann Arbor: The University of Michigan Press.

Medgyes, P. (1992). Native or non-native: who's worth more? ELT Journal, 46(4), 340-349.

Medgyes, P. (1994). The non-native teacher. London: Macmillan Publishers.

Nemtchinova, E. (2005). Host Teachers' Evaluations of Nonnative-English-Speaking Teacher Trainees - A Perspective from the Classroom. TESOL Quarterly, 39(2), 235262.

Pacek, D. (2005). 'Personality not nationality': Foreign students' perceptions of a nonnative speaker lecturer of English at a British university. In E. Llurda (Ed.), NonNative Language Teachers: Perceptions, Challenges and Contributions to the Profession (pp. 243-262). New York: Springer.

Paikeday, T. M. (1985). The Native Speaker is Dead! Toronto/New York: Paikeday Publishing Inc. 
Phillipson, R. (1992). Linguistic Imperialism. Oxford: Oxford University Press.

Piller, I. (2002). Passing for a native speaker: Identity and success in second language learning. Journal of Sociolinguistics, 6(2), 179-206.

Rampton, M. B. H. (1990). Displacing the 'native speaker': expertise, affiliation and inheritance. ELT Journal, 44(2), 97-101.

Reves, T., \& Medgyes, P. (1994). The Non-Native English Speaking EFL/ESL Teacher's Self-Image: An International Survey. System, 22(3), 353-367.

Roberts, C., Davies, E., \& Jupp, T. (1992). Language and Discrimination. Harlow, Essex: Longman.

Samimy, K. K., \& Brutt-Griffler, J. (1999). To Be a Native or Non-Native Speaker: Perceptions of "Non-Native" Students in a Graduate TESOL Program. In G. Braine (Ed.), Non-Native Educators in English Language Teaching (pp. 127-144). Mahwah, New Jersey: Lawrence Erlbaum Associates.

Seidlhofer, B. (1999). Double standards: teacher education in the Expanding Circle. World Englishes, 18(2), 233-245.

Seidlhofer, B. (2001). Closing a conceptual gap: the case for a description of English as a lingua franca. International Journal of Applied Linguistics, 11(2), 133-158.

Sherr, A., Cheung, M., \& Harding, R. (2004). Regulation of Private English Language Teaching Institutions. Retrieved 7 July, 2005, from http://www.britishcouncil.org/learning-eltials-report.doc

TESOL. (1991). A TESOL Statement on Nonnative Speakers of English and Hiring Practices. TESOL Matters, August/September 1992, p.23.

Thomas, J. (1999). Voices from the Periphery: Non-Native Teachers and Issues of Credibility. In G. Braine (Ed.), Non-Native Educators in English Language Teaching (pp. 5-13). Mahwah, New Jersey: Lawrence Erlbaum Associates, Publishers.

Timmis, I. (2002). Native-speaker norms and International English: a classroom view. ELT Journal, 53(3), 240-249.

Universities UK. (2004). Higher education in facts and figures. Retrieved 11 August, 2005, from http://bookshop.universitiesuk.ac.uk/downloads/facts04.pdf

Widdowson, H. G. (1994). The Ownership of English. TESOL Quarterly, 28(2), 377-389. 


\section{Appendix 1: English Language Teaching Institutions Survey}

Dear Colleague,

Thank you very much for agreeing to participate in this questionnaire about English language teaching institutions and programmes in the United Kingdom.

There are two sections to the questionnaire:

I. Administrative Information - This section asks general questions about the courses your institution provides, the students and the instructors.

II. Teacher Recruitment / Professional Development - This section asks for details about how you select and evaluate your instructors.

Please type your answers directly into this Word document and return it by email to: (email address supplied). Or, if you prefer to fill out the survey on paper, please print it out and send it to: (Name and address supplied).

\begin{tabular}{|c|c|c|c|}
\hline \multicolumn{4}{|c|}{ I. ADMINISTRATIVE INFORMATION } \\
\hline \multicolumn{4}{|c|}{ 1. What kind of institution or programme do you work for? (please check box) } \\
\hline & $\begin{array}{l}\text { Private language school (British Council- } \\
\text { accredited) }\end{array}$ & & Private language school (non-accredited) \\
\hline$\square$ & University (foundation programme) & & University (pre-sessional course) \\
\hline$\square$ & FE College & $\square$ & University (in-sessional ESL programme) \\
\hline$\square$ & Other please specify & & \\
\hline
\end{tabular}

\begin{tabular}{|l|l|l|l|}
\hline 2. & What position do you hold? (please check box) & \\
\hline$\square$ & Director of Studies & $\square$ & Head of English Language Teaching \\
\hline$\square$ & Principal & $\square$ & Head of Human Resources/Personnel \\
\hline$\square$ & Other please specify & \\
\hline
\end{tabular}

3. Are you responsible for recruiting English language instructors in your institution or programme? (please check box)

\begin{tabular}{l|l}
$\square$ & Yes: I have full responsibility. \\
\hline
\end{tabular} No

\begin{tabular}{|c|c|c|c|}
\hline 4. & Which of the following courses does & stit & ion provide? (please check box) \\
\hline$\square$ & General English & $\square$ & English for Academic Purposes (EAP) \\
\hline$\square$ & Business English / Executive English & $\square$ & Study Skills \\
\hline
\end{tabular}

5. How many students does your institution have? (please type the number)

\begin{tabular}{|l|l|}
\hline Summertime number: & Rest of the year number: \\
\hline
\end{tabular}

6. Which countries have the highest representation among your students? (please list)

please specify countries 
7. How many English language instructors does your institution employ?

In the summertime number:

Rest of the year number: 


\begin{tabular}{|l|l|}
\hline 8. How many of your institution's instructors are: \\
\hline Female (Native speakers number: & Female (Non-native speakers) number: \\
\hline Male (Native speakers) number: & Male (Non-native speakers) number: \\
\hline
\end{tabular}

\begin{tabular}{|l|l|}
\hline $\begin{array}{l}\text { 9. If your institution employs instructors from outside of the UK, which countries are they } \\
\text { from? }\end{array}$ & Non-Native Speakers please specify countries \\
\hline Native Speakers please specify countries & \\
\hline
\end{tabular}

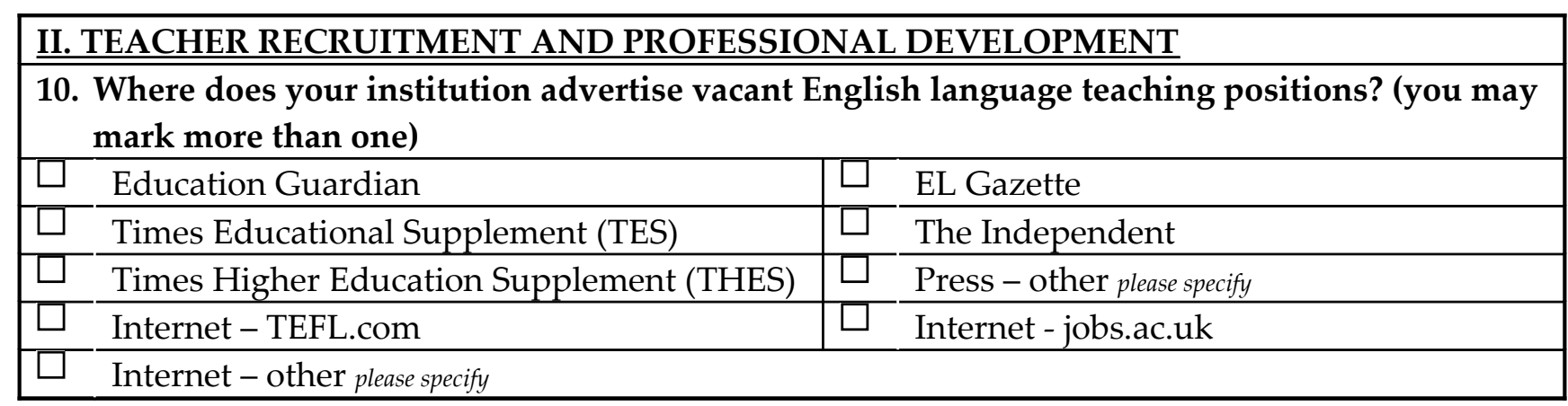

11. When recruiting English language instructors, how important do you consider the following criteria to be? Please check one box for each criterion according to the scale below.

\begin{tabular}{|c|c|c|c|c|c|c|c|c|}
\hline $\mathbf{X}$ & $\mathbf{1}$ & \multicolumn{2}{|c|}{$\mathbf{3}$} & \multicolumn{2}{|c|}{$\mathbf{4}$} & \multicolumn{2}{|c|}{$\mathbf{5}$} \\
\hline $\begin{array}{c}\text { Not } \\
\text { applicable }\end{array}$ & $\begin{array}{c}\text { Not important } \\
\text { at all }\end{array}$ & $\begin{array}{c}\text { Relatively } \\
\text { unimportant }\end{array}$ & $\begin{array}{c}\text { Somewhat } \\
\text { important }\end{array}$ & $\begin{array}{c}\text { Moderately } \\
\text { important }\end{array}$ & $\begin{array}{c}\text { Very } \\
\text { important }\end{array}$ \\
\hline Criterion & $\mathbf{X}$ & $\mathbf{1}$ & $\mathbf{2}$ & $\mathbf{3}$ & $\mathbf{4}$ & $\mathbf{5}$ \\
\hline Accent & $\square$ & $\square$ & $\square$ & $\square$ & $\square$ & $\square$ \\
\hline British nationality & $\square$ & $\square$ & $\square$ & $\square$ & $\square$ & $\square$ \\
\hline Educational background & $\square$ & $\square$ & $\square$ & $\square$ & $\square$ & $\square$ \\
\hline Ethnicity & $\square$ & $\square$ & $\square$ & $\square$ & $\square$ & $\square$ \\
\hline EU Nationality & $\square$ & $\square$ & $\square$ & $\square$ & $\square$ & $\square$ \\
\hline Native English speaker & $\square$ & $\square$ & $\square$ & $\square$ & $\square$ & $\square$ \\
\hline Performance in interview & $\square$ & $\square$ & $\square$ & $\square$ & $\square$ & $\square$ \\
\hline Recommendation & $\square$ & $\square$ & $\square$ & $\square$ & $\square$ & $\square$ \\
\hline Application materials e.g. sample lesson plan & $\square$ & $\square$ & $\square$ & $\square$ & $\square$ & $\square$ \\
\hline Teaching demonstration & $\square$ & $\square$ & $\square$ & $\square$ & $\square$ & $\square$ \\
\hline Teaching experience & $\square$ & $\square$ & $\square$ & $\square$ & $\square$ & $\square$ \\
\hline Veaching qualifications & $\square$ & $\square$ & $\square$ & $\square$ & $\square$ & $\square$ \\
\hline $\begin{array}{l}\text { 12. What other criteria do you use in your recruitment of English language instructors? } \\
\text { please specify }\end{array}$
\end{tabular}

13. What professional development opportunities are available on a pre-service or in-service basis to the instructors in your institution? (You may mark more than one.)

\begin{tabular}{|ll|ll|}
\hline$\square$ & Initial training programme & $\square$ & Observation of other instructors \\
\hline$\square$ & In-service training seminars & $\square$ & Opportunity for further study e.g. DELTA \\
\hline$\square$ & Other please specify & \\
\hline
\end{tabular}

14. Which of the following does your institution use to monitor English language instructors in your school/programme? (You may mark more than one.) \begin{tabular}{l|ll} 
Student evaluations & $\square$ Observations by supervisors
\end{tabular} 
$\square \quad$ Other please specify

Thank you very much for your time. 


\section{Appendix II: Additional Criteria}

\section{Additional Criteria Listed by Respondents for Recruitment of English Language Instructors}

The following criteria are grouped into themes and then listed by group: Private Language Schools (PLS), Universities/Higher Education Institutions (UNI), Further Education Colleges (FE). In general, comments have been kept intact, unless they fall into two or more categories, in which case they have either been duplicated or split into the relevant sections. The original spelling and grammar have been preserved.

\section{Personality / Attitude}

VERY IMPORTANT Personality - lively / enthusiastic / flexible (PLS)

Attitude: Willingness to work in a team / readiness to extend oneself for students both in and outside the classroom (PLS)

evidence of ability to work as part of a team (PLS)

Ability to adapt (PLS)

Do we like them and will they fit in well (PLS)

Friendly, Customer Centred (PLS)

personality, friendliness (PLS)

letter of application (esp. standard of written English, but also general level of

professionalism) (PLS)

Enthusiasm, personality, openness and willingness to learn (PLS)

Personality (PLS)

Evidence of genuine interest in teaching overseas students (PLS)

Empathy with students (IND)

personal attributes eg. Responsible - good communicator (UNI)

general manner (team player, pleasant to work with, reliable) (UNI)

evidence of team working ability (UNI)

communication skills (UNI)

team player, adaptable (UNI)

empathy with other cultures; personality (UNI)

Personality (UNI)

Flexibility, team ethic, initiative (UNI)

Personality, innovativeness, educational philosophy and 'fit' with departmental culture (UNI)

interpersonal skills (FE)

flexibility, adaptability, people skills, team player, resilience (FE)

\section{Other personal characteristics}

Age ie to get a mix of ages (PLS)

personal appearance and gut reaction (PLS) 
presentability (PLS)

\section{Specialised experience, knowledge or qualifications}

We go for the people we think are the best trainer in there area (PLS)

Residential, Pastoral Skills, Other interests to assist recreation programme (PLS)

Other work experience (eg business) (PLS)

Teaching knowledge shown in interview + on application (PLS)

Range of experience especially of different course types (PLS)

must have TEFL (PLS)

overseas experience (PLS)

matching expertise to course type (UNI)

relevant qualifs and relevant EAP experience (UNI)

familiarity with EAP in UK HE institutions (UNI)

overseas teaching experience (UNI)

IT skills (UNI)

develop own materials (UNI)

Amount of overseas teaching experience (UNI)

relevant experience in relation to students being taught (UNI)

Familiarity with subject discipline of students is a bonus (UNI)

Being active professionally (e.g. conference papers) (UNI)

overseas experience (UNI)

Awareness of national agendas (FE)

commitment to equal ops and professional development (FE)

We insist that all teachers are fully qualified and (obviously) have the right to live/work in UK (FE)

\section{Language-related}

letter of application (esp. standard of written English, but also general level of professionalism) (PLS)

language awareness (PLS)

language competence and awareness (UNI),

native-like proficiency rather being a native-speaker (UNI)

\section{Legal}

Able to supply CRB check/willing to undergo check (PLS)

I was a little confused by the 'visa status' box - obviously a teacher must be able to work legally, but was anything else meant? (PLS)

For EU nationality \& for Visa Status I have ticked the relatively unimportant box, but I'd like to qualify that by saying that this is true as long as the employment of the individual is legal and in line with UK law (UNI) 
The nationality questions refers to the ability to legally take employment here (FE)

We insist that all teachers are fully qualified and (obviously) have the right to live/work in UK (FE)

Visa status is obviously important if it affects whether we can employ a person or not. If it doesn't affect this then it is not particularly important (FE)

\section{Probation}

1st week performance on job (PLS)

first week observation, though does not go directly to 'selection', will determine whether the teacher will have work here in anything but the short term (PLS)

\section{Institution-specific}

Christian commitment as we are a Christian School (PLS)

Performance at interview questionnaire (PLS)

Agreement with company mission statement and aims (PLS)

knowledge of (location supplied) (PLS)

Distance needed to travel to work; desire to live and work in (Location supplied) (UNI) we have a full person specification (UNI)

\section{Other}

references (PLS)

who is available at short notice (UNI) 
Table 1 Response Rate By Institution Type

\begin{tabular}{|c|c|c|c|}
\hline \multicolumn{1}{|c|}{ Institution Type } & Sent & Responded & Response rate \\
\hline Private language school & 193 & 50 & $25.9 \%$ \\
\hline University/HE Institution & 78 & 27 & $34.6 \%$ \\
\hline FE/AE College & 54 & 13 & $24.1 \%$ \\
\hline TOTAL & 325 & 90 & $27.7 \%$ \\
\hline
\end{tabular}


Table 2 Mean Rating ${ }^{2}$, Standard Deviation and Mode for Each Criterion

\begin{tabular}{|c|c|c|c|}
\hline Criterion & Mean & $\begin{array}{l}\text { Standard } \\
\text { Deviation }\end{array}$ & Mode \\
\hline Teaching qualifications & 4.72 & .520 & 5 \\
\hline Performance in interview & 4.65 & .546 & 5 \\
\hline Teaching experience & 4.54 & .656 & 5 \\
\hline Educational background & 4.48 & .841 & 5 \\
\hline Recommendation & 4.20 & .846 & 5 \\
\hline Visa status & 4.11 & 1.235 & 5 \\
\hline Native English speaker & 4.05 & 1.187 & 5 \\
\hline Teaching demonstration & 3.59 & 1.366 & 5 \\
\hline $\begin{array}{l}\text { Application materials e.g. } \\
\text { sample lesson plan }\end{array}$ & 3.58 & 1.166 & 4 \\
\hline Accent & 3.11 & 1.250 & 4 \\
\hline British nationality & 2.31 & 1.249 & 1 \\
\hline EU Nationality & 1.94 & 1.377 & 1 \\
\hline Ethnicity & 1.43 & .684 & 1 \\
\hline
\end{tabular}

\footnotetext{
${ }^{2}$ The scale is as follows: $X=$ Not applicable, $1=$ Not important at all, $2=$ Relatively unimportant, $3=$ Somewhat important, 4 = Moderately important, 5 = Very important
} 
Table 3 Number of Responses for Each Criterion with Percentage of Total Respondents (1= Not important at all; 5= Very important)

\begin{tabular}{|c|c|c|c|c|c|c|c|c|}
\hline Criterion & 1 & 2 & 3 & 4 & 5 & $\begin{array}{c}\text { Responses } \\
\text { total }\end{array}$ & N/A & $\begin{array}{c}\text { No } \\
\text { response }\end{array}$ \\
\hline Teaching qualifications & 0 & 0 & $\begin{array}{c}3 \\
(3.3 \%) \\
\end{array}$ & $\begin{array}{c}19 \\
(21.1 \%) \\
\end{array}$ & $\begin{array}{c}68 \\
(75.6 \%) \\
\end{array}$ & $\begin{array}{c}90 \\
(100.0 \%) \\
\end{array}$ & 0 & 0 \\
\hline $\begin{array}{c}\text { Performance in } \\
\text { interview }\end{array}$ & 0 & 0 & $\begin{array}{c}3 \\
(3.3 \%) \\
\end{array}$ & $\begin{array}{c}25 \\
(27.8 \%) \\
\end{array}$ & $\begin{array}{c}61 \\
(67.8 \%) \\
\end{array}$ & $\begin{array}{c}89 \\
(98.9 \%) \\
\end{array}$ & 0 & $\begin{array}{c}1 \\
(1.1 \%) \\
\end{array}$ \\
\hline Teaching experience & 0 & $\begin{array}{c}2 \\
(2.2 \%) \\
\end{array}$ & $\begin{array}{c}2 \\
(2.2 \%) \\
\end{array}$ & $\begin{array}{c}31 \\
(34.4 \%) \\
\end{array}$ & $\begin{array}{c}55 \\
(61.1 \%) \\
\end{array}$ & $\begin{array}{c}90 \\
(100 \%) \\
\end{array}$ & 0 & 0 \\
\hline $\begin{array}{l}\text { Educational } \\
\text { background }\end{array}$ & $\begin{array}{c}1 \\
(1.1 \%)\end{array}$ & $\begin{array}{c}3 \\
(3.3 \%) \\
\end{array}$ & $\begin{array}{c}5 \\
(5.6 \%) \\
\end{array}$ & $\begin{array}{c}23 \\
(25.6 \%) \\
\end{array}$ & $\begin{array}{c}57 \\
(63.3 \%) \\
\end{array}$ & $\begin{array}{c}89 \\
(98.9 \%) \\
\end{array}$ & $\begin{array}{c}1 \\
(1.1 \%) \\
\end{array}$ & 0 \\
\hline Recommendation & $\begin{array}{c}1 \\
(1.1 \%)\end{array}$ & $\begin{array}{c}2 \\
(2.2 \%)\end{array}$ & $\begin{array}{c}12 \\
(13.3 \%)\end{array}$ & $\begin{array}{c}36 \\
(40.0 \%) \\
\end{array}$ & $\begin{array}{c}37 \\
(41.1 \%)\end{array}$ & $\begin{array}{c}88 \\
(97.8 \%)\end{array}$ & $\begin{array}{c}1 \\
(1.1 \%)\end{array}$ & $\begin{array}{c}1 \\
(1.1 \%)\end{array}$ \\
\hline Visa status & $\begin{array}{c}3 \\
(3.3 \%) \\
\end{array}$ & $\begin{array}{c}6 \\
(6.7 \%) \\
\end{array}$ & $\begin{array}{c}4 \\
(4.4 \%) \\
\end{array}$ & $\begin{array}{c}13 \\
(14.4 \%) \\
\end{array}$ & $\begin{array}{c}31 \\
(34.4 \%) \\
\end{array}$ & $\begin{array}{c}57 \\
(63.3 \%) \\
\end{array}$ & $\begin{array}{c}28 \\
(31.1 \%) \\
\end{array}$ & $\begin{array}{c}5 \\
(5.6 \%) \\
\end{array}$ \\
\hline Native English speaker & $\begin{array}{c}5 \\
(5.6 \%) \\
\end{array}$ & $\begin{array}{c}6 \\
(6.7 \%) \\
\end{array}$ & $\begin{array}{c}10 \\
(11.1 \%) \\
\end{array}$ & $\begin{array}{c}24 \\
(26.7 \%) \\
\end{array}$ & $\begin{array}{c}41 \\
(45.6 \%) \\
\end{array}$ & $\begin{array}{c}86 \\
(95.6 \%) \\
\end{array}$ & $\begin{array}{c}3 \\
(3.3 \%) \\
\end{array}$ & $\begin{array}{c}1 \\
(1.1 \%) \\
\end{array}$ \\
\hline $\begin{array}{c}\text { Teaching } \\
\text { demonstration }\end{array}$ & $\begin{array}{c}6 \\
(6.7 \%) \\
\end{array}$ & $\begin{array}{c}8 \\
(8.9 \%) \\
\end{array}$ & $\begin{array}{c}11 \\
(12.2 \%) \\
\end{array}$ & $\begin{array}{c}13 \\
(14.4 \%) \\
\end{array}$ & $\begin{array}{c}21 \\
(23.3 \%) \\
\end{array}$ & $\begin{array}{c}59 \\
(65.6 \%) \\
\end{array}$ & $\begin{array}{c}29 \\
(32.2 \%) \\
\end{array}$ & $\begin{array}{c}2 \\
(2.2 \%) \\
\end{array}$ \\
\hline Application materials & $\begin{array}{c}5 \\
(5.6 \%) \\
\end{array}$ & $\begin{array}{c}7 \\
(7.8 \%) \\
\end{array}$ & $\begin{array}{c}20 \\
(22.2 \%) \\
\end{array}$ & $\begin{array}{c}23 \\
(25.6 \%) \\
\end{array}$ & $\begin{array}{c}18 \\
(20.0 \%) \\
\end{array}$ & $\begin{array}{c}73 \\
(81.1 \%) \\
\end{array}$ & $\begin{array}{c}16 \\
(17.8 \%) \\
\end{array}$ & $\begin{array}{c}1 \\
(1.1 \%) \\
\end{array}$ \\
\hline Accent & $\begin{array}{c}12 \\
(13.3 \%)\end{array}$ & $\begin{array}{c}13 \\
(14.4 \% \\
)\end{array}$ & $\begin{array}{c}23 \\
(25.6 \%)\end{array}$ & $\begin{array}{c}24 \\
(26.7 \%)\end{array}$ & $\begin{array}{c}11 \\
(12.2 \%)\end{array}$ & $\begin{array}{c}83 \\
(92.2 \%)\end{array}$ & $\begin{array}{c}4 \\
(4.4 \%)\end{array}$ & $\begin{array}{c}3 \\
(3.3 \%)\end{array}$ \\
\hline British nationality & $\begin{array}{c}24 \\
(26.7 \%)\end{array}$ & $\begin{array}{c}23 \\
(25.6 \% \\
\quad) \\
\end{array}$ & $\begin{array}{c}12 \\
(13.3 \%)\end{array}$ & $\begin{array}{c}10 \\
(11.1 \%)\end{array}$ & $\begin{array}{c}5 \\
(5.6 \%)\end{array}$ & $\begin{array}{c}74 \\
(82.2 \%)\end{array}$ & $\begin{array}{c}14 \\
(15.6 \%)\end{array}$ & $\begin{array}{c}2 \\
(2.2 \%)\end{array}$ \\
\hline EU Nationality & $\begin{array}{c}37 \\
(41.1 \%)\end{array}$ & $\begin{array}{c}9 \\
(10.0 \% \\
)\end{array}$ & $\begin{array}{c}5 \\
(5.6 \%)\end{array}$ & $\begin{array}{c}5 \\
(5.6 \%)\end{array}$ & $\begin{array}{c}6 \\
(6.7 \%)\end{array}$ & $\begin{array}{c}62 \\
(68.9 \%)\end{array}$ & $\begin{array}{c}27 \\
(30.0 \%)\end{array}$ & $\begin{array}{c}1 \\
(1.1 \%)\end{array}$ \\
\hline Ethnicity & $\begin{array}{c}44 \\
(48.9 \\
\%)\end{array}$ & $\begin{array}{c}14 \\
(15.6 \% \\
)\end{array}$ & $\begin{array}{c}7 \\
(7.8 \%)\end{array}$ & 0 & 0 & $\begin{array}{c}65 \\
(72.2 \%)\end{array}$ & $\begin{array}{c}24 \\
(26.7 \%)\end{array}$ & $\begin{array}{c}1 \\
(1.1 \%)\end{array}$ \\
\hline
\end{tabular}


Table 4 Cross-tabulation of NES Criterion and Employment of NNES teachers

\begin{tabular}{|c|c|c|c|c|c|c|c|}
\hline \multirow{4}{*}{$\begin{array}{l}\text { Employ } \\
\text { NNESs? }\end{array}$} & \multirow{3}{*}{$\begin{array}{l}\text { no } \\
\text { yes } \\
\end{array}$} & $\begin{array}{l}\text { Not important } \\
\text { at all (1) }\end{array}$ & $\begin{array}{c}\text { I } \\
\text { Relatively } \\
\text { unimportant } \\
\text { (2) }\end{array}$ & $\begin{array}{l}\text { Somewhat } \\
\text { criterio } \\
\text { important } \\
\text { (3) }\end{array}$ & $\begin{array}{c}\text { Moderately } \\
\text { important } \\
(4)\end{array}$ & $\begin{array}{c}\text { Very } \\
\text { important } \\
(5) \\
\end{array}$ & Total \\
\hline & & 4 & 1 & 4 & 17 & 35 & 61 \\
\hline & & 1 & 5 & 6 & 6 & 6 & 24 \\
\hline & Total & 5 & 6 & 10 & 23 & 41 & 85 \\
\hline
\end{tabular}


Table 5 Countries of Non-UK Teachers (Number of respondents who listed the country)

\begin{tabular}{|l|l|}
\hline \multicolumn{1}{|c|}{ NESs } & \\
\hline United States (15) & Poland (5) \\
\hline Australia (14) & Holland (3) \\
\hline New Zealand (9) & Italy (3) \\
\hline Canada (8) & France (2) \\
\hline Republic of Ireland (4) & Germany (2) \\
\hline South Africa (3) & Greece (2) \\
\hline Malaysia (2) & Turkey (2) \\
\hline & Argentina (1) \\
\hline & Austria (1) \\
\hline & Belgium (1) \\
\hline & Czech Republic (1) \\
\hline & Hungary (1) \\
\hline & Luxembourg (1) \\
\hline & Russia (1) \\
\hline & Switzerland (1) \\
\hline & Taiwan (1) \\
\hline & \\
\hline & \\
\hline & \\
\hline & \\
\hline & \\
& \\
&
\end{tabular}


Fig. 1. Native English Speaker Criterion (All Respondents)

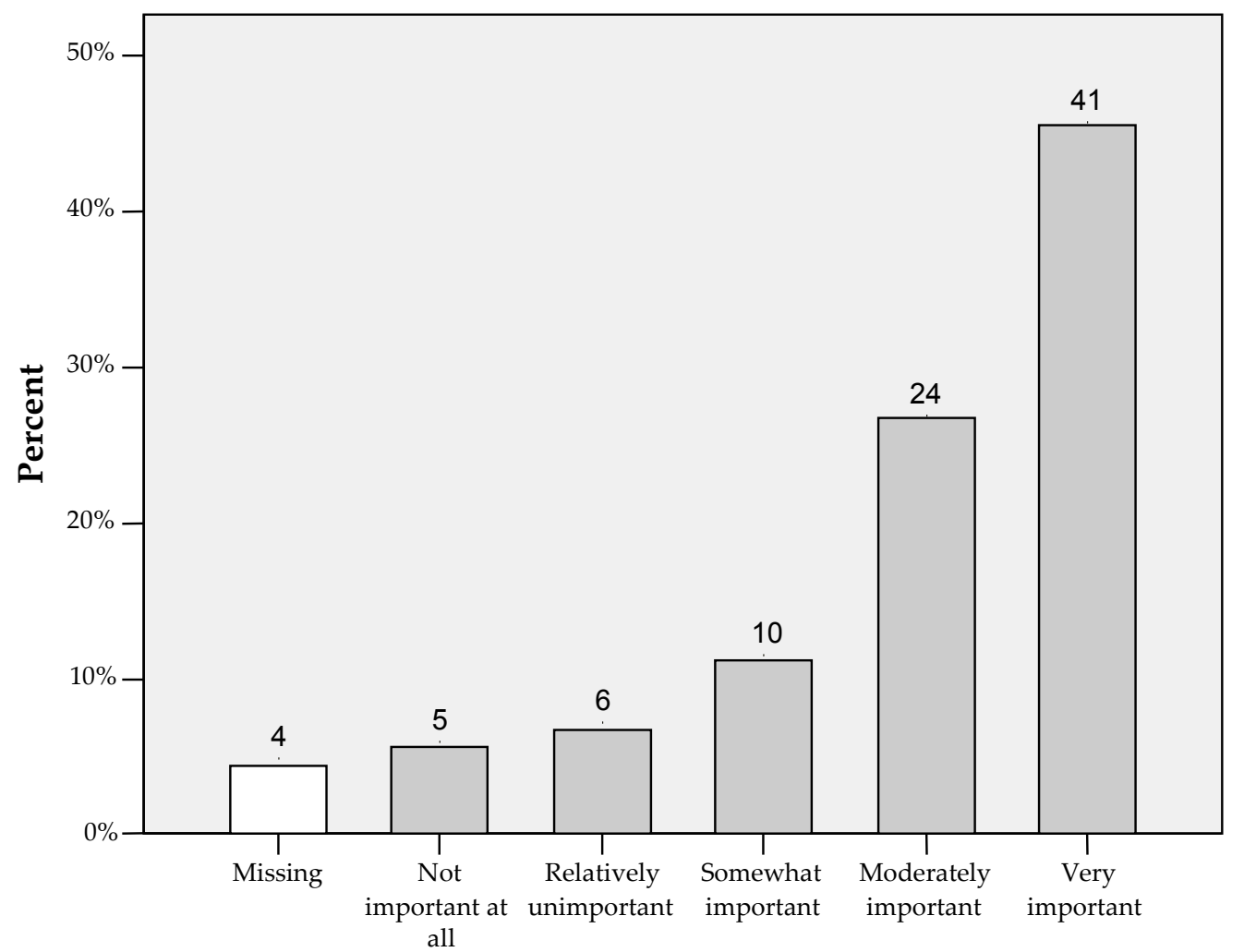

Missing: 1 no response (1.1\%), 3 not applicable (3.3\%) 
Fig. 2. Native English Speaker Criterion (Private Language Schools)

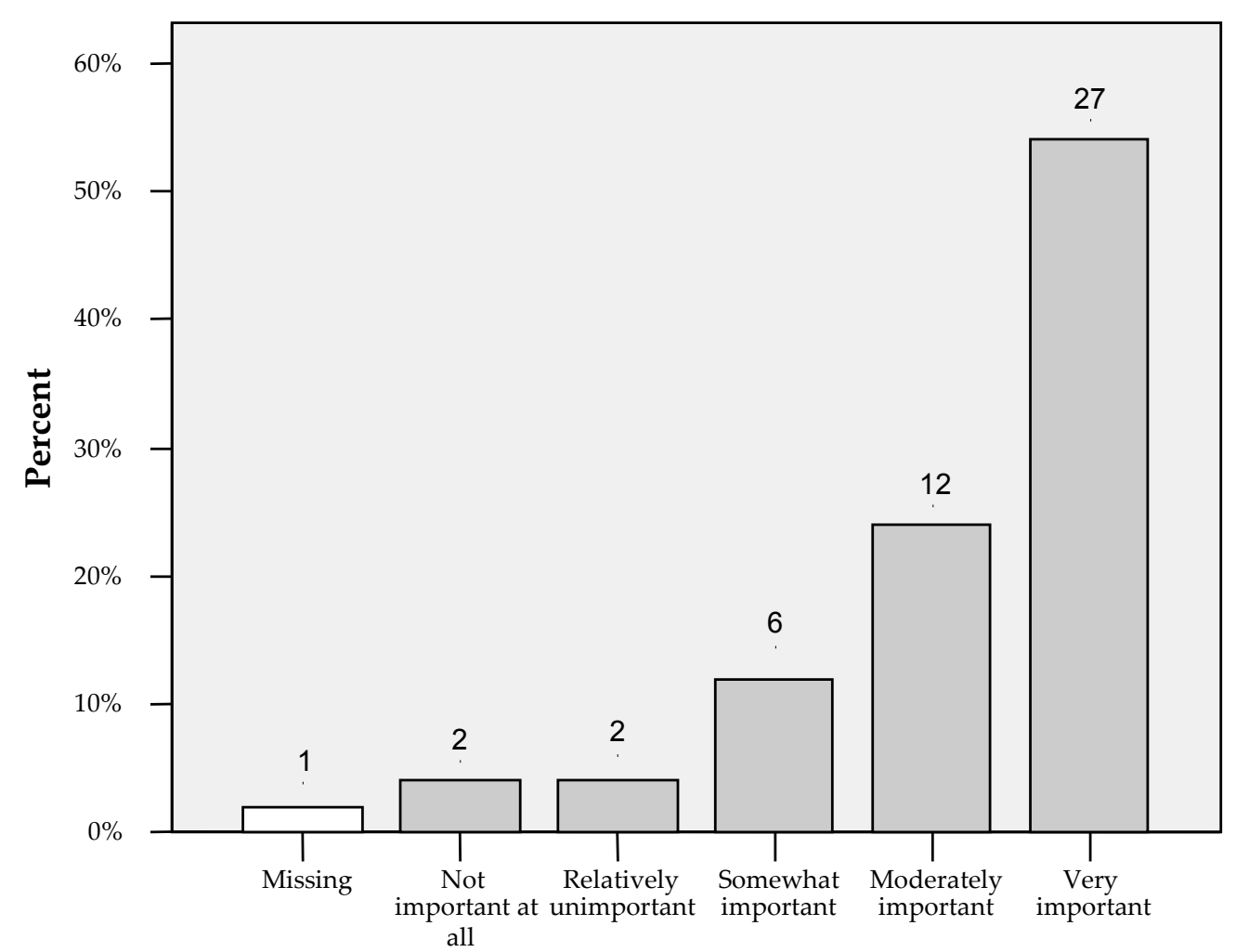

Missing: 1 not applicable (2\%) 
Fig. 3. Native English Speaker Criterion (Universities)

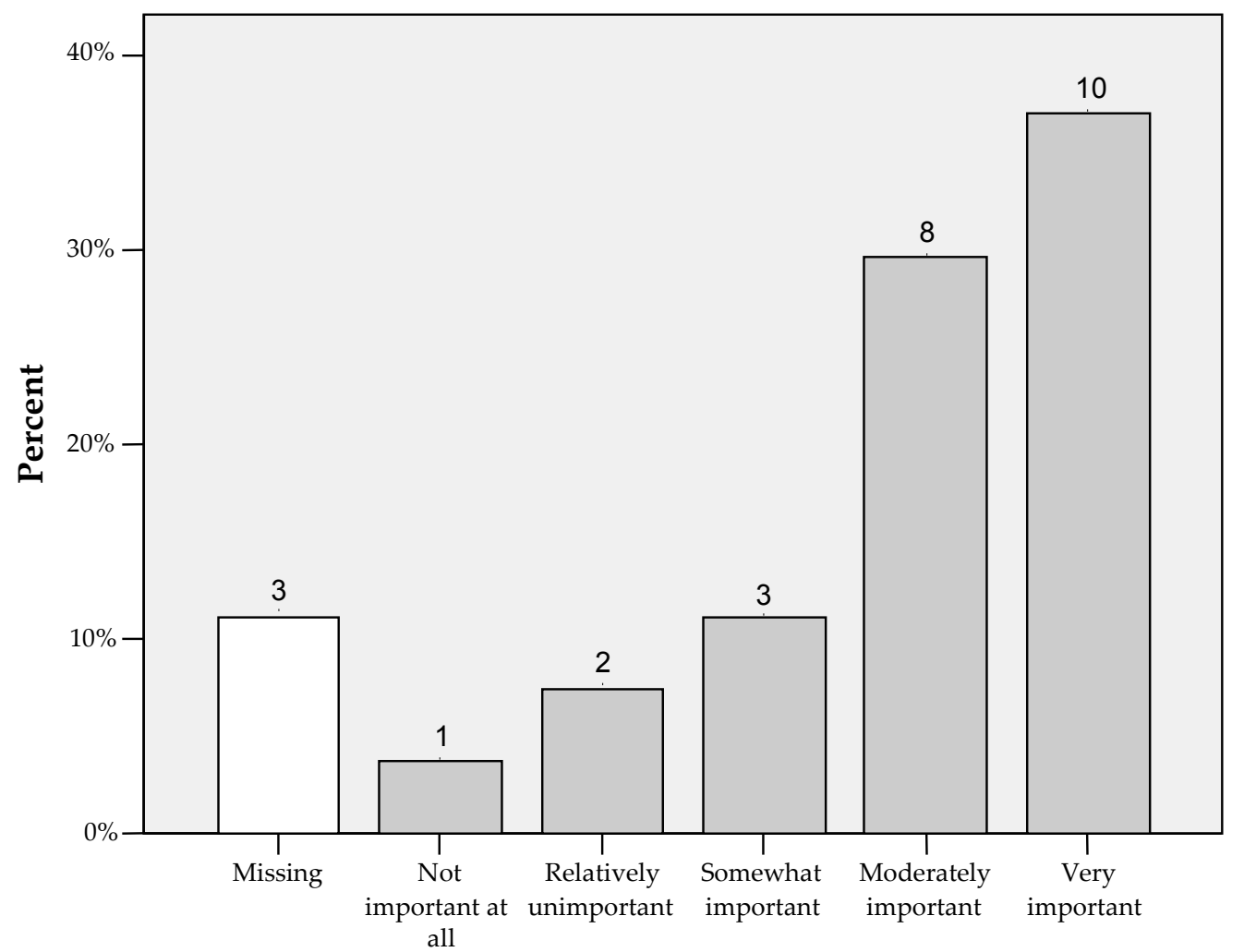

Missing: 1 no response (3.7\%), 2 not applicable (7.4\%) 
Fig. 4. Native English Speaker Criterion (FE Colleges)

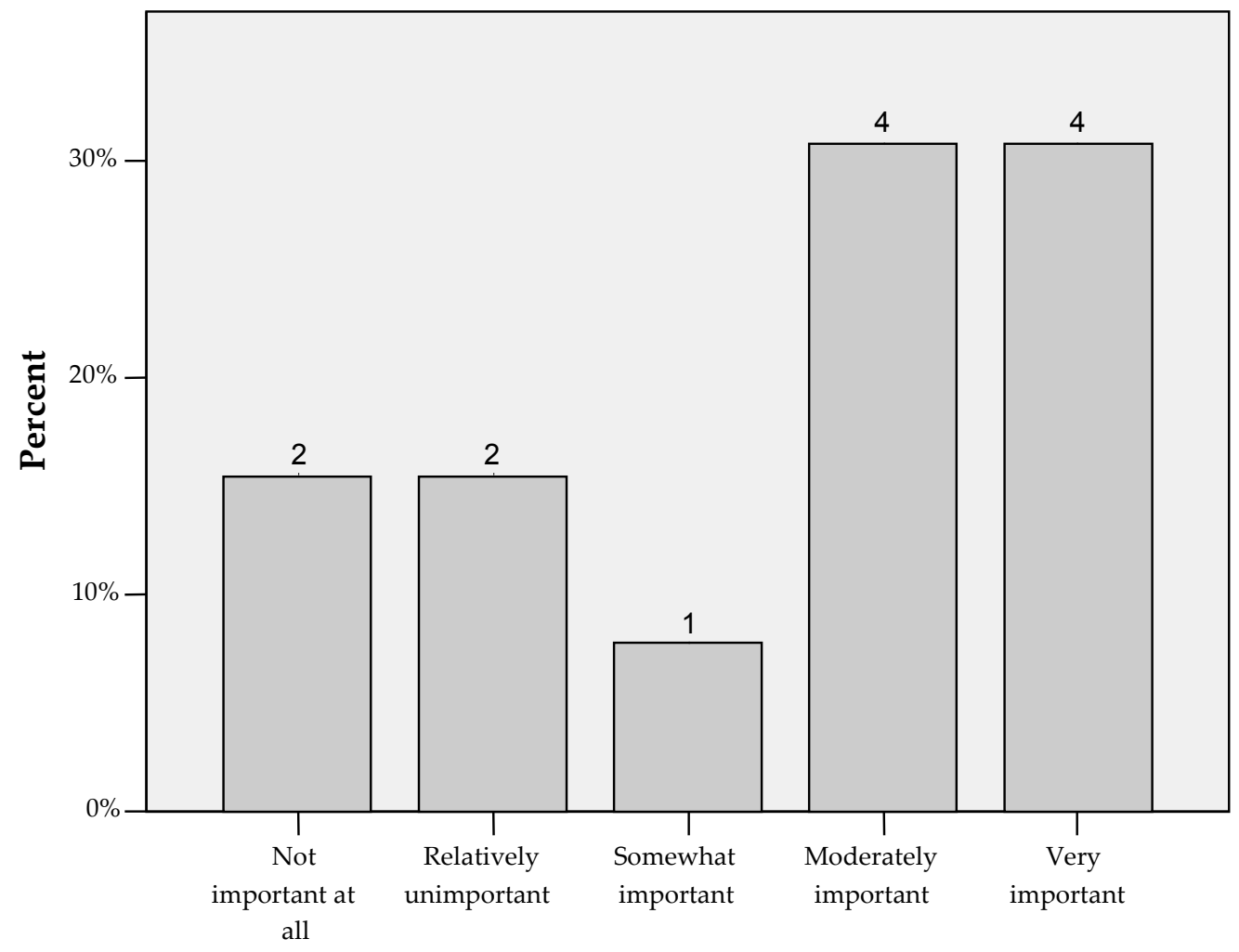

No missing cases 